\title{
Studi Zona Mineralisasi Emas Menggunakan Metode Magnetik Di Lokasi Tambang Emas Poboya
}

\section{(Gold mineralized zone studies using magnetic methods has been conducted in Poboya gold mine site)}

\author{
Mohamad Junaedy ${ }^{*}$, Rustan Efendi, Sandra. \\ Program Studi Fisika Jurusan Fisika FMIPA, Universitas Tadulako, Palu, Indonesia
}

\begin{abstract}
The research of gold mineralized zone using magnetic methods has been conducted in Poboya Gold Mine Site. This study aims to determine the distribution zone of gold mineralization at the mine site. The stages in research using magnetic methods were the acquisition of field data, make corrections IGRF and daily variation, which in turn makes data processing anomaly contour map using surfer 10, perform 2D modeling using software Mag2dc. The results showed that the zone of gold mineralization at the study site in association some minerals such as pyrite $\left(\mathrm{FeS}_{2}\right)$, Chalcopyrite (CuFeS2), Troilite, Pyrrhotites, Porpiri, and Siderite with susceptibility value of 0.000035 SI - SI 0,005, 0.000023 SI - SI 0.0004, 0.00061 SI - SI 0.0017, 0.00046 SI - SI 1.4, 0.00025 SI - 0.21 SI, and SI 0.0013 - 0.011 SI, respectively. These values were associated to igneous rocks, iron sulfides and magnetic minerals. The rocks spreading of gold mineral carrier were located on the east side and the south to the northern part of the research sites with an average depth of between \pm 70 to \pm 320 meters below the ground surface.
\end{abstract}

Keywords : Magnetic Method, Anomaly, Gold Mineralization, Surfer 10, Mag2dc.

\begin{abstract}
ABSTRAK
Telah dilakukan penelitian tentang studi zona mineralisasi emas menggunakan metode magnetik di Lokasi Tambang Emas Poboya. Penelitian ini bertujuan untuk mengetahui sebaran zona mineralisasi emas di lokasi tambang tersebut. Tahapan dalam penelitian menggunakan metode magnetik adalah akuisisi data lapangan, melakukan koreksi IGRF dan variasi harian, pengolahan data yang selanjutnya membuat peta kontur anomali menggunakan surfer 10, melakukan pemodelan 2D menggunakan software Mag2dc. Hasil penelitian menunjukan bahwa zona mineralisasi emas di lokasi penelitian berasosiasi dengan mineral lain seperti Pirit $\left(\mathrm{FeS}_{2}\right)$, Kalkopirit $(\mathrm{CuFeS})$, Troilite, Pyrrhotites, Porpiri dan Siderite dengan nilai suseptibilitas masing-masing 0,000035 SI - 0,005 SI, 0,000023 SI 0,0004 SI, 0,00061 SI - 0,0017 SI, 0,00046 SI - 1,4 SI, 0,00025 SI - 0,21 SI, dan 0,0013 SI 0,011 SI, yang berasosiasi dengan batuan beku, iron sulfides dan mineral magnetik. Penyebaran batuan-batuan pembawa mineral emas ini terdapat pada sisi bagian timur dan selatan hingga pada bagian utara lokasi penelitian dengan kedalaman rata-rata antara \pm 70 meter sampai \pm 320 meter bawah muka tanah.
\end{abstract}

Kata kunci : Metode Magnetik, Anomali, Mineralisasi Emas, Surfer 10, Mag2dc 


\section{LATAR BELAKANG}

Emas adalah mineral logam mulia yang merupakan salah satu komoditas pertambangan yang utama. Pembentukannya berhubungan dengan naiknya larutan sisa magma ke atas permukaan yang dikenal dengan istilah larutan hidrotermal. Pergerakan larutan hidrotermal dikontrol oleh zona lemah yang membentuk rongga sehingga memungkinkan larutan hidrotermal tersebut bermigrasi dan kemudian terakumulasi membentuk suatu endapan yang terletak di bawah permukaan (Peter dalam Ulinna'mah, 2011).

Dilihat dari kondisi fisik alam, emas juga sebagai mineral yang terbentuk bersama-sama dengan mineral lain dan sebagai hasil dari proses magmatisme yang berasal dalam dapur magma, kemudian menerobos ke atas permukaan dalam lingkungan hidrotermal baik sudah mengalami pelapukan maupun belum terlapuk. Terdapat 2 jenis mineral pembawa bijih emas, yaitu mineral yang mengandung logam dan non logam (gangue) baik dalam endapan sulfida rendah maupun endapan sulfida tinggi. Mineral tersebut meliputi kuarsa, adularia, alunit, pirit, kaolinit, smectit/illit, klorit, dan kalkopirit (Faeyumi, 2012).

Salah satu wilayah di Sulawesi Tengah yang memiliki potensi mineral emas sangat besar, yaitu terdapat di Kelurahan Poboya Kecamatan Mantikulore yang dikenal sebagai tambang rakyat dengan luas areal tambang $49.460 \mathrm{Ha}$ yang meliputi daerah pegunungan antara Kota Palu dan Parigi, dan saat ini lokasi yang menjadi aktivitas penambangan rakyat dengan luas sebesar 7.120 Ha (ESDM, 2011). Aktivitas penambangan emas di lokasi Tambang Emas Poboya bukan hanya masyarakat dari Kota Palu saja, akan tetapi dari luar Sulawesi Tengah juga dan sampai saat ini telah banyak penambang yang melakukan aktivitas penambangan emas dengan cara menggali tanah dalam bentuk sumur-sumur yang diduga mengandung butiran biji emas.

Penambangan emas yang dilakukan oleh masyarakat sangat disayangkan karena mereka tidak memperhatikan aspekaspek kelestarian lingkungan sekitar, mereka hanya dengan menggali saja dan memindahkan material dengan tidak terencana sehingga hal ini sangat berdampak pada rusaknya ekosistem lingkungan di Poboya (Walhi dalam Alpinus, 2010). Selain itu, kegiatan penambangan emas sudah masuk pada Kawasan Konservasi Hutan Lindung dengan luas sekitar 7.000, yaitu Tahura Poboya (Poboya-Paneki) yang dilindungi oleh pihak Pemerintah Berdasarkan Surat Keputusan Menteri Kehutanan RI No. 461/Kpts-II/1995 Ha (Silo, 2011). 
Penelitian yang pernah dilakukan oleh Alpinus (2010), pemetaan lapisan pembawa emas dengan titik lokasi pengukuran berada pada batas lintang $0^{0} 61 ' 31$ ' S sampai 0061'49" $\mathrm{S}$ dan batas bujur 119056'44" E sampai 119057'11” E. Penelitian yang dilakukan ini hanya sebatas untuk menentukan struktur lapisan bawah permukaan menggunakan Metode Geolistrik Konfngurasi Wenner dengan mengambil hanya 5 titik pengukuran saja atau dapat dikatakan pengukuran yang dilakukan tidak merata dan hanya mencangkupi sekitaran daerah aliran sungai Poboya dan tidak sampai pada Tahura Poboya, sehingga hal ini yang melatar belakangi peneliti melakukan penelitian dengan menerapkan salah satu metode dalam geofisika lainnya, yaitu Metode Magnetik.

Metode magnetik adalah salah satu metode geofisika yang memanfaatkan sifat kemagnetan bumi yang disebabkan oleh adanya variasi distribusi yang termagnetisasi di bawah permukaan bumi. Metode ini didasarkan pada perbedaan tingkat magnetisasi suatu batuan yang diinduksi oleh medan magnet bumi. Hal ini terjadi sebagai akibat adanya perbedaan sifat kemagnetan suatu material (Ismail, 2010). Metode ini sering juga digunakan dalam eksplorasi minyak bumi, panas bumi, batuan mineral, serta diterapkan pada pencarian prospeksi bendabenda arkeologi (Siahaan, 2009).

a) Gaya Magnetik $(F)$

Dasar dari metode magnetik adalah gaya Coulomb (Telford dalam Siahaan, 2009) antara dua kutub magnetik $m_{1}$ dan $m_{2}$ yang berjarak $r(\mathrm{~cm})$ dalam bentuk persamaan :

$\vec{F}=\frac{m_{1} m_{2}}{\mu_{0} r^{2}} \vec{r}$

Dimana $\vec{F}$ adalah gaya antara dua magnet dengan kuat medan magnet $m_{1}$ dan $m_{2} \cdot \mu_{0}$ adalah permeabilitas medium yang melingkupi kedua magnet.

b) Kuat Medan Magnet $(H)$

Kuat medan magnetik pada suatu titik dengan jarak $r$ dari muatannya dapat dinyatakan sebagai :

$\vec{H}=\frac{m_{1}}{\mu_{0} r^{2}} \vec{r}$

c) Intensitas Kemagnetan (I)

Apabila benda tersebut diletakan dalam suatu medan luar, maka benda tersebut akan termagnetisasi karena induksi. Maka intensitas kemagnetan dapat didefenisikan sebagai tingkat kemampuan menyearahkan momenmomen magnetik dalam medan magnetik luar dapat juga didefinisikan sebagai momen magnetik persatuan volume, yaitu :

$\vec{I}=\frac{\vec{M}}{\text { Volume }}$ 
d) Suseptibilitas Kemagnetan

Suseptibilitas kemagnetan diberi simbol

$k$, merupakan kemampuan benda termagnetisasi yang didefinisikan :

$$
k=\frac{\vec{I}}{H}
$$

Tabel 1 Nilai suseptibilitas beberapa jenis batuan/mineral.

\begin{tabular}{|c|c|c|}
\hline Batuan/Mineral & $\begin{array}{c}\text { Persatuan Volume } \\
k\left(10^{-6} \mathrm{SI}\right) \\
\end{array}$ & $\begin{array}{l}\text { Persatuan Massa } \\
\chi\left(10^{-8} \mathrm{~m}^{3} \mathrm{~kg}^{-1}\right) \mathrm{cgs} \\
\end{array}$ \\
\hline \multicolumn{3}{|l|}{ Batuan Beku } \\
\hline Basal & $250-180.000$ & $8.4-6.100$ \\
\hline Diabase & $1.000-160.000$ & $35-5.600$ \\
\hline Porpiri & $250-210.000$ & $9.2-7.700$ \\
\hline Rhyolite & $250-38.000$ & $10-1.500$ \\
\hline Gabro & $1.000-90.000$ & $26-3.000$ \\
\hline \multicolumn{3}{|l|}{ Batuan Sedimen } \\
\hline Red sediments & $10-100$ & $0.5-5$ \\
\hline Shale & $63-18.600$ & $3-886$ \\
\hline \multicolumn{3}{|l|}{ Batuan Metamorf } \\
\hline Quartzite & 4.400 & 170 \\
\hline Granulite & $3.000-30.000$ & $100-1.000$ \\
\hline Serpentine & $3.100-18.000$ & $110-630$ \\
\hline Slate & $0-38.000$ & $0-1.400$ \\
\hline Rata-rata batuan metamorf & $0-73.0000$ & $0-2.600$ \\
\hline \multicolumn{3}{|l|}{ Mineral Non-magnetik } \\
\hline Calcite & $-7.5-(-39)$ & $-0.3-(-1.4)$ \\
\hline Halite & $-10-(-16)$ & $-0.48-(-0.75)$ \\
\hline Galena & -33 & -0.44 \\
\hline Magnesit & -15 & $-0,48$ \\
\hline \multicolumn{3}{|l|}{ Mineral Magnetik } \\
\hline Garnets & 2.700 & 69 \\
\hline Biotites & $1.500-2.900$ & $52-98$ \\
\hline Siderite & $1.300-11.000$ & $32-270$ \\
\hline Chromite & $3.000-120.000$ & $63-2.500$ \\
\hline \multicolumn{3}{|l|}{ Iron Sulfides } \\
\hline Kalkopirit $\left(\mathrm{CuFeS}_{2}\right)$ & $23-400$ & $0.55-10$ \\
\hline Arsenopirit & 3.000 & 50 \\
\hline Troilite & $610-1.700$ & $13-36$ \\
\hline Pyrrhotites & $460-1.400 .000$ & $10-30.000$ \\
\hline Pirit $\left(\mathrm{FeS}_{2}\right)$ & $35-5.000$ & $1-100$ \\
\hline \multicolumn{3}{|l|}{ Iron-Titanium Oxides } \\
\hline Hematit $\left(\mathrm{Fe}_{2} \mathrm{O}_{3}\right)$ & $500-40.000$ & $10-760$ \\
\hline Titanomagnetit & $130.000-620.000$ & $2.500-12.000$ \\
\hline \multicolumn{3}{|l|}{ Other-Iron-Bearing Minerals } \\
\hline Geothite & $1.100-12.000$ & $26-280$ \\
\hline Limonite & $2.800-3.100$ & $66-74$ \\
\hline
\end{tabular}

Sumber : (Hunt, Moskowitz dan Banerjee, 1995)

Beberapa nilai suseptibilitas batuan/mineral dapat lihat pada Tabel 1 . Semua material bumi, baik berupa unsur ataupun senyawa dan sebagainya, ditinjau dari sifat-sifat kemagnetannya pada umumnya terbagi dalam kelompokkelompok (Rosanti, 2012) :

1. Diamagnetik. Mempunyai kerentanan magnetik $(k)$ dengan nilai yang sangat kecil. Contoh materialnya: grafit, gypsum, marmer, kwartz, garam.
2. Paramagnetik. Mempunyai harga kerentanan magnetik $(k)$ positif dengan nilai yang kecil. Contoh materialnya: Kapur.

3. Ferromagnetik. Mempunyai harga kerentanan magnetik $(k)$ positif dengan nilai yang besar. Sifat kemagnetan subtansi ini dipengaruhi oleh temperatur, yaitu pada suhu di atas suhu curie, sifat kemagnetannya hilang. Contoh materialnya: pyrite, magnetit, hematit, dan lain-lain.

4. Antiferromagnetik adalah benda magnetik yang mempunyai nilai $(k)$ sangat kecil, yaitu mendekati nilai $k$ pada benda paramagnetik. Contoh materialnya: $\mathrm{Fe}_{2} \mathrm{O}_{3}$ (hematite, geothite).

5. Ferrimagnetik adalah benda magnetik yang mempunyai nilai $k$ tinggi tetapi jauh lebih rendah dari bahan ferromagnetic. Contoh materialnya: $\mathrm{Fe}_{2} \mathrm{~S}$ (magnetite, pyrotite, maghmemite, gregeite.

Anomali yang diperoleh dari survei merupakan hasil gabungan medan magnetik remanen dan induksi, bila arah medan magnetik remanen sama dengan arah medan magnet induksi maka anomalinya bertambah besar. Demikian pula sebaliknya, dalam survei magnetik efek medan remanen akan diabaikan apabila anomali medan magnetik kurang dari 25\% medan magnet utama bumi. Dengan demikian anomali

\section{Studi Zona Mineralisasi Emas Menggunakan Metode Magnetik Di Lokasi Tambang Emas Poboya} (Mohamad Junaedy) 
magnetik yang diamati (Telford, 1976), dengan persamaan :

$\Delta T=T_{o b s}-T_{I G R F} \pm T_{V H}$

dimana :

$\Delta T=$ Anomali Magnetik

$T_{\text {obs }}=$ Medan magnet total yang terukur

$T_{I G R F}=$ Medan magnet teoritis berdasarkan

IGRF

$T_{V H}=$ Koreksi medan magnet variasi harian

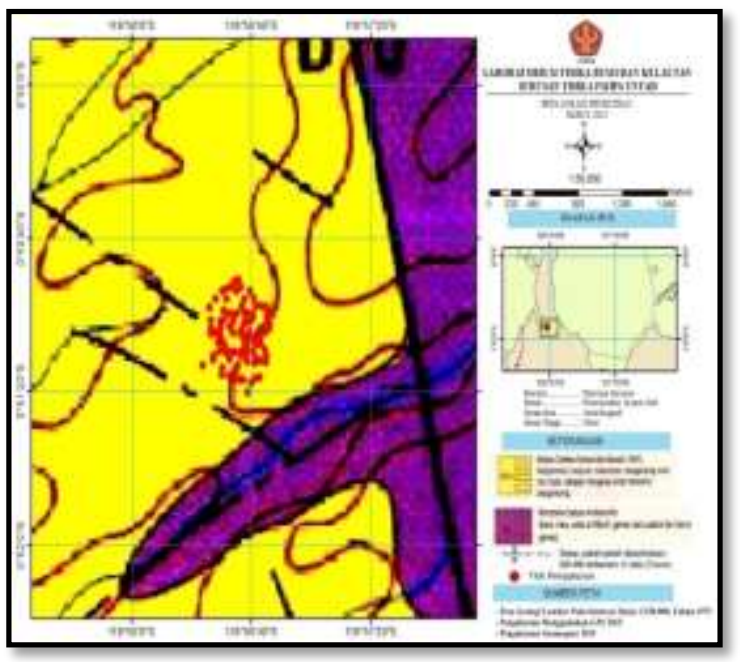

Gambar 1 Peta Geologi Lokasi Penelitian

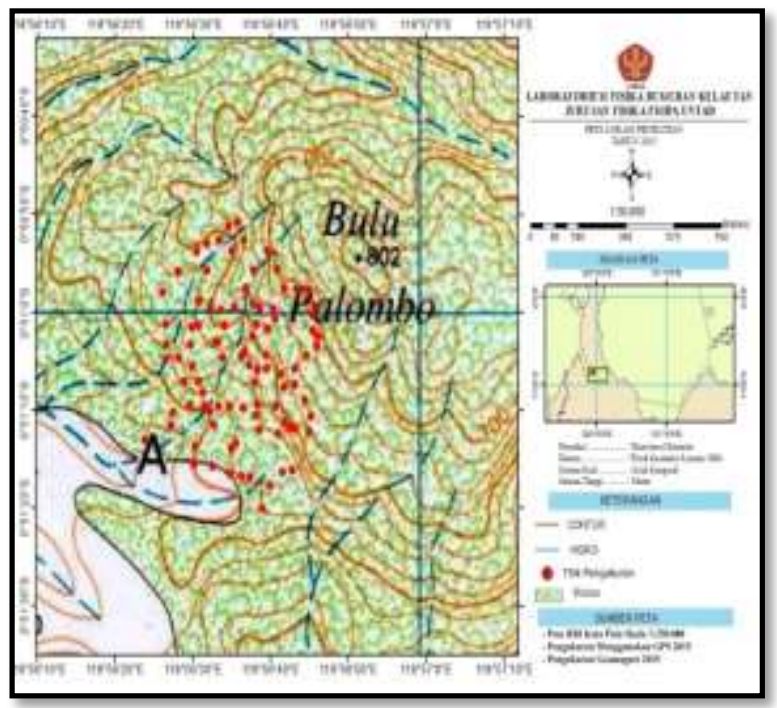

Gambar 2 Peta Lokasi Penelitian
Berdasarkan Peta Geologi Lembar Palu, Sulawesi (Sukamto, 1973) (Gambar 1), bahwa batuan penyusun stratigrafi Daerah Poboya dan sekitarnya merupakan :

a. Formasi Molasa Celebes

Penyebaran batuan ini terdapat di bagian barat dan timur mengelilingi batuan endapan alluvium, meluas ke bagian utara dan menyempit di bagian selatan. Batuan penyusun ini terdiri dari konglomerat, batupasir, batulumpur, batugamping-koral dan napal yang semuanya hanya mengeras lemah, batuan ini diduga berumur Meosen.

b. Kompleks Batuan Metamorf

Batuan metamorf ini merupakan batuan paling tertua di daerah ini yang hanya tersingkap pada pematang timur dan merupakan intinya. Kompleks ini terdiri dari sekis anfibiolit, sekis, genes dan pualam. Sekis banyak terdapat pada sisi bagian barat, sedangkan genes dan pualam terdapat banyak pada sisi timur.Tubuh-tubuh instrusi yang tak terpetakan, umunya selebar dari 50 meter, menerobos kompleks batuan metamorf dengan berjangka dari diorit hingga granodiorit. Batuan ini diduga berumur pra-tersier hingga paleozoikum.

Berdasarkan pengamatan saat melakukan pengukuran di lokasi tambang emas Kelurahan Poboya, terlihat bahwa 
kondisi morfologinya terdiri dari perbukitan dan sedikit dataran. Morfologi perbukitan berada bagian timur yang memanjang dari arah selatan ke utara dengan ketinggian \pm 750 meter di atas permukaan laut yang merupakan bagian tengah lokasi penelitian. Vegetasi terdiri dari pepohonan kecil yang diselingi semak belukar pada wilayah morfologi perbukitan dan hutan. Sedangkan morfologi pada bagian dataran berada pada bagian barat pemukiman warga dengan ketinggian \pm 200 meter di atas permukaan laut.

\section{METODE PENELITIAN}

Lokasi pengukuran menggunakan metode magnetik terletak Kelurahan Poboya, Kecamatan Mantikulore, Kota Palu, Propinsi Sulawesi Tengah dengan batas lintang $0^{\circ} 51^{\prime} 50,6^{\prime \prime}$ LS sampai $0^{\circ} 50^{\prime}$ 21,0" LS dan batas bujur $119^{\circ} 56^{\prime} 58,5^{\prime \prime}$ BT sampai $119^{\circ} 56^{\prime} 25,5^{\prime \prime}$ BT. Total luas areal pengukuran mencapai $\pm 915,312 \mathrm{~m}^{2}$ x 1.020 $\mathrm{m}^{2}$. Seperti yang terlihat pada Gambar 2 .

\section{HASIL}

Data yang diperoleh dari hasil pengukuran adalah posisi titik pengukuran (lintang dan bujur), waktu dan medan magnet di titik pengukuran. Untuk mendapatkan nilai anomali medan magnet $(\Delta \mathrm{T})$ dilakukan koreksi sebagai berikut :

1. Koreksi harian
Untuk mendapatkan koreksi harian $\left(\mathrm{T}_{\mathrm{VH}}\right)$, maka dibuat grafik hubungan antara $\left(\mathrm{T}_{\mathrm{obs}}\right)$ pada data base station terhadap waktu. Masing-masing grafik tersebut dapat memberikan persamaan yang kemudian digunakan untuk mengoreksi data ( $\left.\mathrm{T}_{\mathrm{obs}}\right)$ pada data mobile yang disebut dengan $\left(\mathrm{T}_{\text {cor }}\right)$.

\section{Koreksi IGRF}

Data input yang digunakan pada saat mengakses data IGRF secara online yaitu posisi koordinat lokasi penelitian dan waktu pengukuran. Nilai koreksi IGRF di lokasi Tambang emas Poboya saat pengukuran adalah 41338,3 nT.

3. Peta Anomali Magnetik

Berdasarkan data medan magnet yang terukur $\left(\mathrm{T}_{\mathrm{obs}}\right)$ di lapangan, selanjutnya dilakukan perhitungan anomali magnetik $\left(\Delta \mathrm{T}_{\text {total }}\right)$ dengan menggunakan software surfer 10 seperti pada Gambar 3 yang terlihat bahwa.

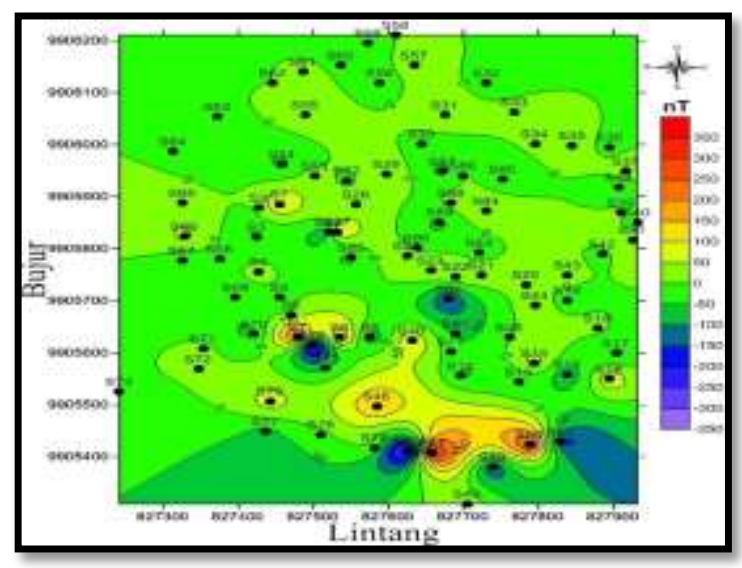

Gambar 3 Peta kontur anomali medan magnet total $\left(\Delta \mathrm{T}_{\text {total }}\right)$ 
Peta anomali magnetik yang diperoleh seperti pada Gambar 3 menunjukkan adanya kontras kontur medan magnet di titik pengukuran. Titik pengukuran yang kontras kontur medan magnetnya menunjukkan adanya sebaran anomali di lokasi penelitian di beberapa tempat yang mengandung anomali yang tinggi (high intensity) bernilai positif dan anomali yang rendah (low intensity) bernilai negatif.

Peta kontur anomali medan magnet total $\left(\Delta \mathrm{T}_{\text {total }}\right)$ yang diperoleh dari hasil koreksi adalah gabungan dari anomali medan magnet regional dan anomali medan magnet residual. Untuk itu perlu dilakukan pemisahan antara anomali medan magnet regional dan anomali medan magnet residual dengan menggunakan software Numeri. Hasil peta kontur anomali medan magnet regional dan residual dapat dilihat pada Gambar 4 dan Gambar 5.

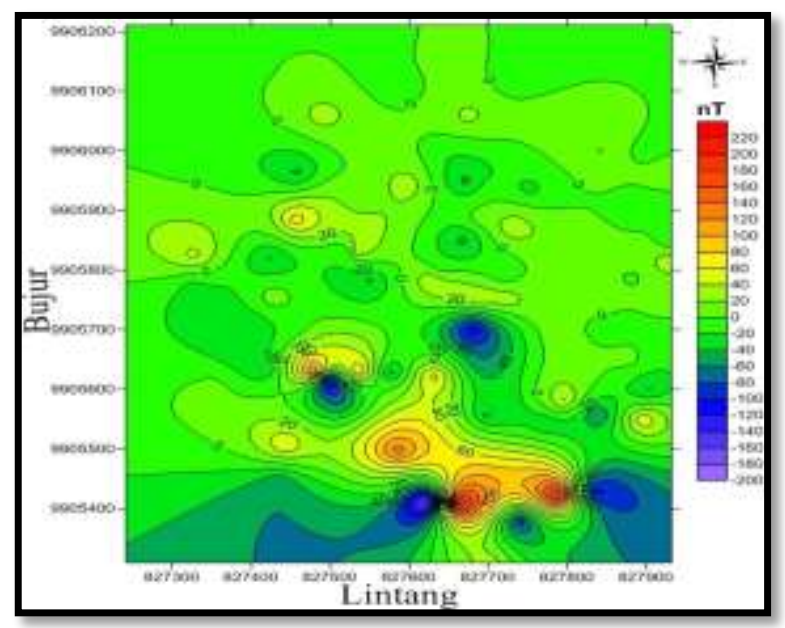

Gambar 4 Peta kontur anomali medan magnet regional

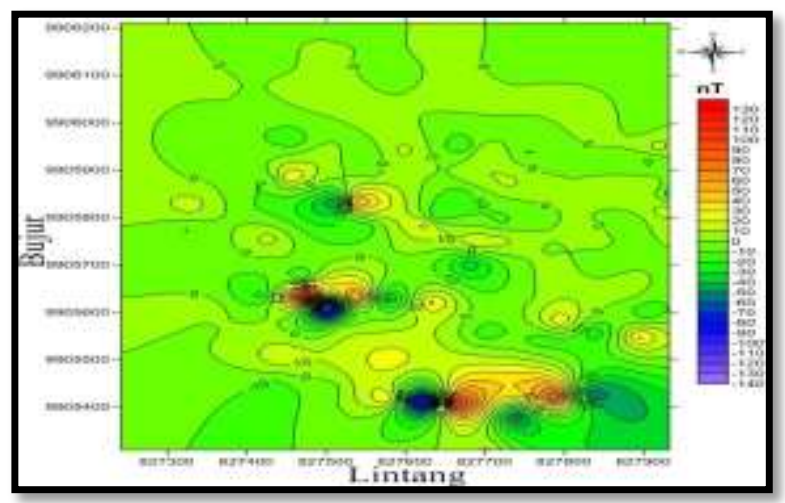

Gambar 5 Peta kontur anomali medan magnet residual

\section{PEMBAHASAN}

Pemodelan dilakukan menggunakan software Mag2dc berdasarkan data sayatan yang akan digunakan untuk membuat model penampang. Adapun sayatan yang dipilih pada peta anomali magnetik residual dapat dilihat pada Gambar 6 . Sayatan yang dipilih berdasarkan pada perbedaan kontur medan magnet pada peta anomali magnetik. Sayatan-sayatan tersebut dibuat saling berpotangan untuk memudahkan dalam interpretasi data dan keakuratan data yang akan digunakan untuk pemodelan 2D. Masing-masing sayatan A$\mathrm{A}^{\prime}$ berarah barat - timur dengan panjang sayatan \pm 695 meter, model sayatan B-B' dengan arah utara - selatan dengan panjang sayatan \pm 890 meter, model sayatan C-C', D-D' dan E-E' memiliki arah model sayatan yang sama, yaitu baratlaut - tenggara dengan masing-masing panjang sayatan $\mathrm{C}$ $C^{\prime} \pm 776$ meter, sayatan D-D' \pm 995 meter, dan sayatan E-E' \pm 930 meter. 


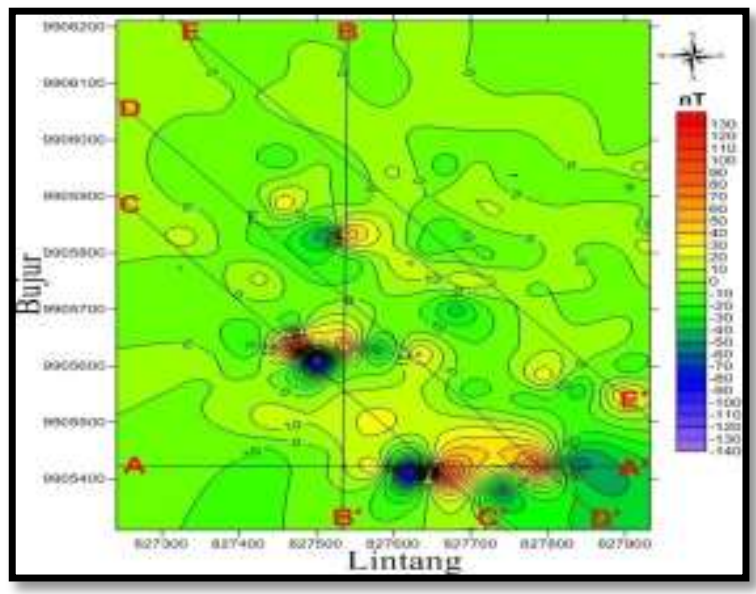

Gambar 6 Model Sayatan pada peta kontur anomali medan magnet residual

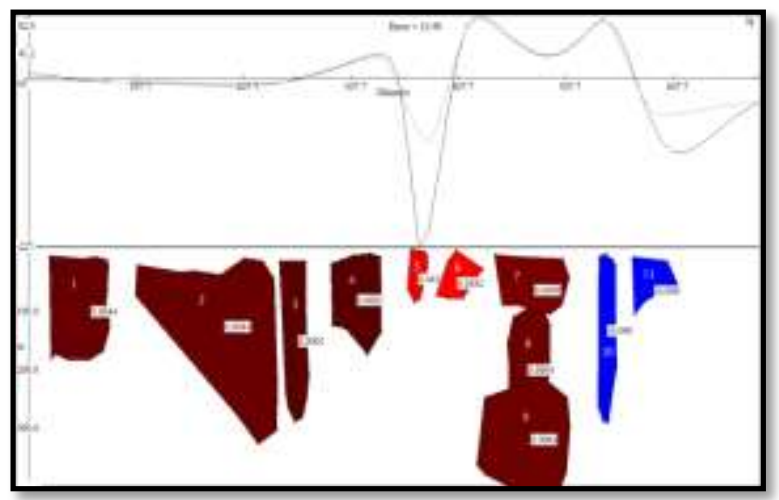

Gambar 7 Kurva dan bentuk benda anomali hasil pemodelan sayatan A-A'.(Error antara data pengukuran dan hasil pemodelan sebesar $13,58 \%)$.

Berdasarkan hasil pemodelan Mag2dc yang telah dilakukan tampak bahwa struktur dari batuan-batuan tersebut tidak beraturan dikarenakan batuan tersebuat mengalami proses pelapukan atau proses tektonik. Nilai suseptibilitas batuan hasil pemodelan ditunjukan pada Gambar 7 sampai Gambar 11 merupakan gambaran zona mineralisasi emas bawah permukaan daerah penelitian. Benda-benda yang dihasilkan pada pemodelan 2D setiap sayatan memberikan nilai-nilai suseptibilitas yang negatif dan positif. Benda-benda yang memiliki nilai suseptibilitas negatif diinterpretasikan sebagai respon mineral non-magnetik. Jenis mineral tidak dapat ditentukan karena tidak terdapat kesesuaian antara nilai suseptibilitas pada setiap benda dengan nilai suseptibilitas batuan/mineral dalam literatur. Sedang untuk benda yang memiliki nilai positif dapat ditentukan jenis batuan/mineral karena ada kesesuaian nilai suseptiblitasnya pada literatur. Nilai susebtibilitas yang diperoleh dari pemodelan untuk sayatan AA', B-B', C-C', D-D', dan E-E' dapat dilihat pada Tabel 2.

Tabel 2 Interpretasi jenis batuan/mineral terhadap nilai suseptibilitas pada benda hasil pemodelan 2D pada sayatan A-A', B-B', C-C', D-D', dan E-E'

\begin{tabular}{|c|c|c|c|c|}
\hline \multirow{2}{*}{ No } & \multicolumn{2}{|c|}{ Nilai Suseptibilitias (SI) } & \multirow{3}{*}{$\begin{array}{c}\text { Interpretasi } \\
\text { Jenis Minera//Batuan } \\
\end{array}$} & \multirow{2}{*}{ Keterangan } \\
\hline & Benda & Literatur & & \\
\hline \multirow{2}{*}{\multicolumn{4}{|c|}{ Pirit }} & \\
\hline & \multirow{4}{*}{0,0044} & $0,000035-0,005$ & Pirit $(\mathrm{FeS} 2)$ & Iron sulfides \\
\hline \multirow{3}{*}{1} & & 0,0044 & Kuarsa & Batuan metamorf \\
\hline & & $0,0013-0,011$ & Siderite & Mineral magnetik \\
\hline & & $0,0031-0,018$ & Serpentine & Batuan metamorf \\
\hline \multirow{4}{*}{2} & \multirow{4}{*}{0,0044} & $0,000035-0,005$ & Pirit $(\mathrm{FeS} 2)$ & Iron sulfides \\
\hline & & 0,0044 & Kuarsa & Batuan metamorf \\
\hline & & $0,0013-0,011$ & Siderite & Mineral magnetik \\
\hline & & $0,0031-0,018$ & Serpentine & Batuan metamorf \\
\hline \multirow{2}{*}{3} & \multirow{2}{*}{0,0001} & $0,000023-0,0004$ & Kalkopirit $(\mathrm{CuFeS})$ & Iron sulfides \\
\hline & & $0,00001-0,0001$ & Red sediments & Batua sedimen \\
\hline \multirow{2}{*}{4} & \multirow{2}{*}{0,0001} & $0,000023-0,0004$ & Kalkopirit $(\mathrm{CuFeS} 2)$ & Iron sulfides \\
\hline & & $0,00001-0,0001$ & Red sediments & Batuan sedimen \\
\hline \multirow{2}{*}{5} & \multirow{2}{*}{0,0432} & $0-0,073$ & Rata $^{2}$ b. metamorf & Batuan metamorf \\
\hline & & $0,001-0,09$ & Gabro & Batuan beku \\
\hline 6 & 00482 & $0-0,073$ & Rata $^{2}$ b. metamorf & Batuan metamorf \\
\hline & 0,0482 & $0,001-0,09$ & Gabro & Batuan beku \\
\hline & & $0,0011-0,012$ & Geothite & Other-iron-bearing mineral \\
\hline & 00110 & $0,0013-0,011$ & Siderite & Mineral magnetik \\
\hline 7 & 0,0110 & $0,0031-0,018$ & Serpentine & Batuan metamorf \\
\hline & & $0,000063-0,0186$ & Shale & Batuan sedimen \\
\hline & & $0,0011-0,012$ & Geothite & Other-iron-bearing mineral \\
\hline 8 & 0,0064 & $0,00025-0,21$ & Porpiri & Batuan beku \\
\hline & & $0,0013-0,011$ & Siderite & Mineral magnetik \\
\hline & & $0,0011-0,012$ & Geothite & Other-iron-bearing mineral \\
\hline 9 & 0,0064 & $0,00025-0,21$ & Porpiri & Batuan beku \\
\hline & & $0,0013-0,011$ & Siderite & Mineral magnetik \\
\hline 10 & $-0,098$ & $-5+2+$ & - & Mineral non-magnetik \\
\hline 11 & $-0,099$ & - & - & Mineral non-magnetik \\
\hline & B-B' & & & \\
\hline 1 & 00016 & $0,000035-0,005$ & Pirit $(F e S 2)$ & Iron sulfides \\
\hline 1 & 0,0016 & $0,0013-0,011$ & Siderite & Mineral magnetik \\
\hline & & $0-0,073$ & Rata $^{2}$ b. metamorf & Batuan metamorf \\
\hline 2 & 0,0472 & $0,001-0,09$ & Gabro & Batuan beku \\
\hline & & $0,0011-0,012$ & Geothite & Other-iron-bearing minerals \\
\hline 3 & 0,0069 & $0,00025-0,21$ & Porpiri & Batuan beku \\
\hline & & $0,0013-0,011$ & Siderite & Mineral magnetik \\
\hline 4 & 0,0010 & $0,000035-0,005$ & Pirit $(\mathrm{FeS} 2)$ & Iron sulfides \\
\hline & & $0,0011-0,012$ & Geothite & Other-iron-bearing minerals \\
\hline 5 & 0,0058 & $0,00025-0,21$ & Porpiri & Batuan beku \\
\hline & & $0,0013-0,011$ & Siderite & Mineral magnetik \\
\hline 6 & 0,0027 & $0,000035-0,005$ & Pirit $(\mathrm{FeS} 2)$ & Iron sulfides \\
\hline & & $0,0013-0,011$ & Siderite & Mineral magnetik \\
\hline & 0,0056 & $0,0011-0,012$ & Geothite & Other-iron-bearing mineral \\
\hline 7 & & $0,00025-0,21$ & Porpiri & Batuan beku \\
\hline & & $0,0013-0,011$ & Siderite & Mineral magnetik \\
\hline 8 & 000001 & $0,000023-0,0004$ & Kalkopirit $(\mathrm{CuFeS} 2)$ & Iron sulfides \\
\hline 8 & 0,0001 & $0,00001-0,0001$ & Red sediments & Batua sedimen \\
\hline 0 & 00018 & $0,000035-0,005$ & Pirit $(\mathrm{FeS} 2)$ & Iron sulfides \\
\hline 9 & 0,0018 & $0,0013-0,011$ & Siderite & Mineral magnetik \\
\hline & C.C' & & & \\
\hline & 00001 & $0,000023-0,0004$ & Kalkopirit $\left(\mathrm{CuFeS}_{2}\right)$ & Iron sulfides \\
\hline 1 & 0,0001 & $0,00001-0,0001$ & Red sediments & Batua sedimen \\
\hline 2 & $-0,006$ & & - & Mineral Non-magnetik \\
\hline & & $0,0011-0,012$ & Geothite & Other-iron-bearing minerals \\
\hline 3 & 0,0086 & $0,00025-0,21$ & Porpiri & Batuan beku \\
\hline & & $0,0013-0,011$ & Siderite & Mineral magnetik \\
\hline 4 & $-0,038$ & - & - & Mineral Non-magnetik \\
\hline 5 & $-0,024$ & & & Mineral Non-magnetik \\
\hline & & $0,000035-0,005$ & Pirit $(\mathrm{FeS}$ ) & Iron sulfides \\
\hline 6 & 0,0044 & 0,0044 & Kuarsa & Batuan metamorf \\
\hline & & $0,0013-0,011$ & Siderite & Mineral magnetik \\
\hline
\end{tabular}

Studi Zona Mineralisasi Emas Menggunakan Metode Magnetik Di Lokasi Tambang Emas Poboya (Mohamad Junaedy) 
Agustus 2016

\begin{tabular}{|c|c|c|c|c|}
\hline 7 & $-0,002$ & 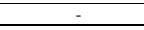 & & Mineral Non-magnetik \\
\hline \multirow{2}{*}{8} & \multirow{2}{*}{0,0001} & $0,000023-0,0004$ & Kalkopirit $\left(\mathrm{CuFeS}_{2}\right)$ & Iron sulfides \\
\hline & & $0,00001-0,0001$ & Red sediments & Batua sedimen \\
\hline 9 & $\begin{array}{ll}-0,026 \\
\end{array}$ & - & & Mineral Non-magnetik \\
\hline \multirow[b]{2}{*}{10} & \multirow{2}{*}{0,0036} & $0,000035-0,005$ & Pirit (FeS2) & Iron sulfides \\
\hline & & $0,0013-0,011$ & Siderite & Mineral magnetik \\
\hline \multicolumn{5}{|c|}{\begin{tabular}{|l} 
Sayatan D-D' \\
\end{tabular}} \\
\hline \multirow{3}{*}{1} & \multirow{3}{*}{0,0005} & $0,0005-0,04$ & Hematit $\left(\mathrm{Fe}_{2} \mathrm{O}_{3}\right)$ & Iron-titanium oxides \\
\hline & & $0,00025-0,21$ & Porpiri & Batuan beku \\
\hline & & $0,00046-1,4$ & Pyrrhotites & Iron sulfides \\
\hline \multirow{3}{*}{2} & \multirow{3}{*}{0,0005} & $0,0005-0,04$ & Hematit $\left(\mathrm{Fe}_{2} \mathrm{O}_{3}\right)$ & Iron-titanium oxides \\
\hline & & $0,00025-0,21$ & Porpiri & Batuan beku \\
\hline & & $0,00046-1,4$ & Pyrrhotites & Iron sulfides \\
\hline \multirow{3}{*}{3} & \multirow{3}{*}{0,0057} & $0,0011-0,012$ & Geothite & Other-iron-bearing minerals \\
\hline & & $0,00025-0,21$ & Porpiri & Batuan beku \\
\hline & & $0,0013-0,011$ & Siderite & Mineral magnetik \\
\hline 4 & 0,0176 & $0,000063-0,0186$ & Shale & Batuan sedimen \\
\hline 5 & $-0,005$ & - & 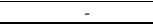 & Mineral non-magnetik \\
\hline 6 & $-0,002$ & - & & Mineral non-magnetik \\
\hline \multirow{2}{*}{7} & \multirow{2}{*}{0,0024} & $0,000035-0,005$ & Pirit $(\mathrm{FeS} 2)$ & Iron sulfides \\
\hline & & $0,0013-0,011$ & Siderite & $\begin{array}{l}\text { Mineral magnetik } \\
\end{array}$ \\
\hline \multirow[b]{2}{*}{8} & \multirow{2}{*}{0,0018} & $0,000035-0,005$ & Pirit (FeS2) & Iron sulfides \\
\hline & & $0,0013-0,011$ & Siderite & Mineral magnetik \\
\hline 9 & 0,0194 & $0-0,0209$ & Sandstone & Batuan sedimen \\
\hline 10 & $-0,002$ & - & - & Mineral non-magnetik \\
\hline 11 & 0,0101 & $0,0011-0,012$ & Geothite & Other-iron-bearing minerals \\
\hline \multicolumn{5}{|c|}{ Sayatan E-E' } \\
\hline 1 & $-0,000$ & - & - & Mineral non-magnetik \\
\hline 2 & $-0,000$ & - & - & Mineral non-magnetik \\
\hline 3 & $-0,010$ & - & & Mineral non-magnetik \\
\hline \multirow{2}{*}{4} & \multirow{2}{*}{0,0036} & $0,000035-0,005$ & Pirit $(\mathrm{FeS} 2)$ & Iron sulfides \\
\hline & & $0,0013-0,011$ & Siderite & Mineral magnetik \\
\hline \multirow{2}{*}{5} & \multirow{2}{*}{0,0018} & $0,000035-0,005$ & Pirit (FeS2) & Iron sulfides \\
\hline & & $0,0013-0,011$ & Siderite & Mineral magnetik \\
\hline \multirow[b]{2}{*}{6} & \multirow{2}{*}{0,0038} & $0,000035-0,005$ & Pirit $(\mathrm{FeS2})$ & Iron sulfides \\
\hline & & $0,0013-0,011$ & Siderite & Mineral magnetik \\
\hline \multirow[b]{2}{*}{7} & & $0,000035-0,005$ & Pirit $(\mathrm{FeS} 2)$ & Iron sulfides \\
\hline & 0,0019 & $0,0013-0,011$ & Siderite & Mineral magnetik \\
\hline & & $0,000023-0,0004$ & Kalkopirit $\left(\mathrm{CuFeS}_{2}\right)$ & Iron Sulfides \\
\hline 8 & 0,0001 & $0,00001-0,0001$ & Red sediments & Batua sedimen \\
\hline & & $0,000023-0,0004$ & Kalkopirit $\left(\mathrm{CuFeS}_{2}\right)$ & Iron sulfides \\
\hline 9 & 0,0001 & $\begin{array}{c}0,00001-0,0001 \\
\end{array}$ & Red sediments & Batua sedimen \\
\hline 10 & 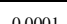 & $0,000023-0,0004$ & Kalkopirit $(\mathrm{CuFeS} 2)$ & Iron sulfides \\
\hline 10 & 0,0001 & $\begin{array}{r}0,00001-0,0001 \\
\end{array}$ & Red sediments & Batua sedimen \\
\hline & & $0,0005-0,04$ & Hematit $\left(\mathrm{Fe}_{2} \mathrm{O}_{3}\right)$ & Iron-titanium oxides \\
\hline 11 & 0,0008 & $0,00025-0,21$ & Porpiri & Batuan beku \\
\hline 11 & 0,0000 & $0,00061-0,0017$ & Troilite & Iron sulfides \\
\hline & & $0,00046-1,4$ & Pyrrhotites & $\begin{array}{l}\text { Iron sulfides } \\
\end{array}$ \\
\hline
\end{tabular}

Model sayatan A-A' pada Gambar 7 yang berarah barat - timur, diperoleh 11 bentuk batuan yang memiliki nilai suseptibilitas yang berbeda-beda, dari ke-11 bentuk batuan tersebut terdapat 6 buah benda yang memiliki nilai kontras suseptibilitas yaitu, benda 1 dan benda 2 dengan nilai suseptibilitas sama, yaitu 0,0044 SI diinterpretasikan sebagai pirit, benda 3 dan benda 4 juga memiliki nilai suseptibilitas sama 0,0001 SI yang diinterpretasikan sebagai kalkoporit, benda 8 dan 9 juga memiliki nilai suseptibilitas yang sama yaitu 0,0064 SI diinterpretasikan sebagai porpiri. Letak kedalaman antara 50 meter - 350 meter dan merupakan batuan pembawa mineral emas.
Model sayatan B-B' dengan arah utara - selatan yang terlihat pada Gambar 8, diperoleh 9 bentuk batuan yang memiliki nilai suseptibilitas yang berbeda-beda, dari ke-9 bentuk batuan tersebut terdapat 8 benda (benda 1, 3, 4, 5, 6, 7, 8, dan 9) yang memiliki nilai kontras suseptibilitas yaitu, benda $1,4,6$ dan 9 dengan nilai suseptibilitas nasing-masing 0,0016 SI, 0,0010 SI, 0,0027 SI dan 0,0018 SI yang keempatnya diinterpretasikan sebagai pirit, benda 3, 5, dan 7 dengan nilai suseptibilitas masing-masing 0,0069 SI, 0,0058 SI, dan 0,0056 SI, ketiganya diinterpretasikan sebagai porpiri, sedang benda 8 dengan nilai suseptibilitas 0,0001 SI diinterpretasikan sebagai kalkopirit dan kedalaman antara 90 meter - 220 meter dan merupakan batuan pembawa mineral emas.

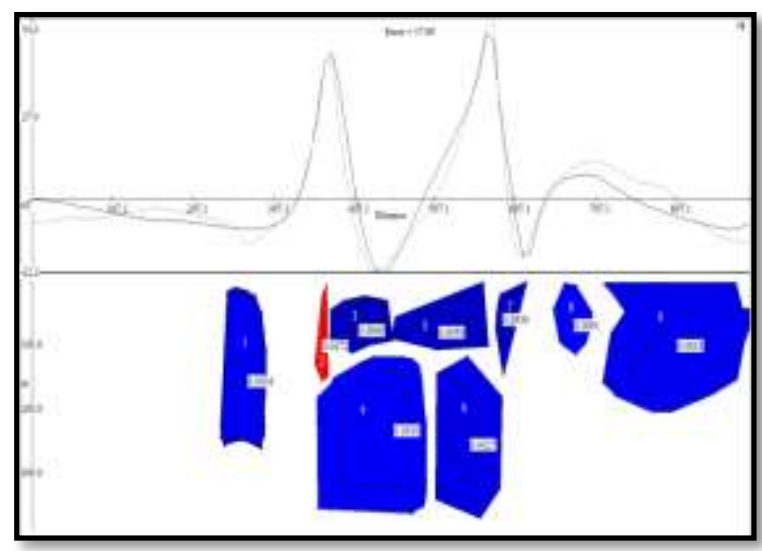

Gambar 8 Kurva dan bentuk benda anomali hasil pemodelan sayatan B-B'. (Error antara data pengukuran dan hasil pemodelan sebesar $17,89 \%)$.

Model sayatan C-C' pada Gambar 9, yang berarah baratlaut - tenggara, diperoleh 10 bentuk batuan yang yang memiliki nilai suseptibilitas yang berbeda-beda, dari ke-10 
bentuk batuan tersebut terdapat 5 buah benda yang memiliki nilai kontras suseptibilitas yaitu, benda 1 dan benda 8 memiliki nilai suseptibilitas yang sama, yaitu 0,0001 SI diinterpretasikan sebagai kalkopirit, benda 3 dengan nilai suseptibilitas 0,0086 SI diinterpretasikan sebagai porpiri, benda 6 dan benda 10 dengan nilai suseptibilitas masing-masing 0,0044 SI dan 0,0036 SI diinterpretasikan sebagai pirit. Kedalaman antara 90 meter 280 meter dan merupakan batuan pembawa mineral emas.

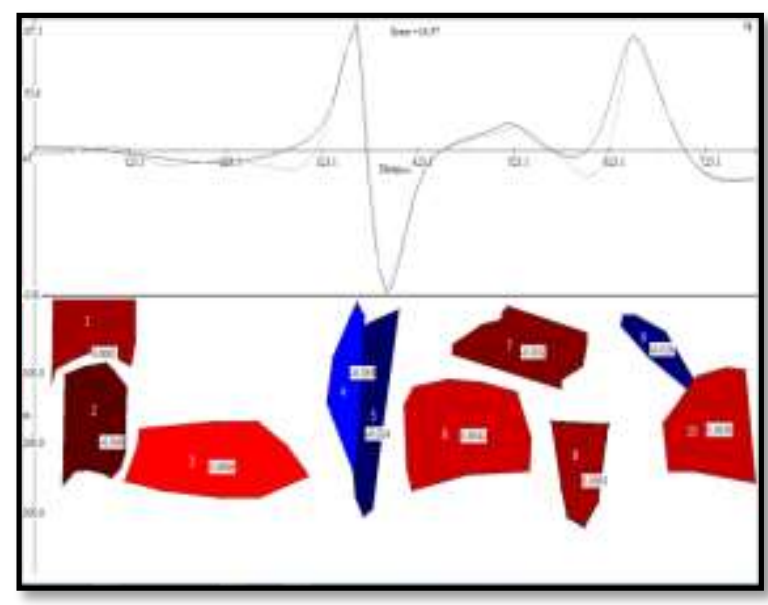

Gambar 9 Kurva dan bentuk benda anomali hasil pemodelan sayatan C-C'.(Error antara data pengukuran dan hasil pemodelan sebesar $16,57 \%)$.

Model sayatan D-D' yang berarah baratlaut - tenggara pada Gambar 10, diperoleh 11 bentuk batuan yang yang memiliki nilai suseptibilitas yang berbedabeda, dari ke-11 bentuk batuan tersebut terdapat 5 buah benda yang memiliki nilai kontras suseptibilitas yaitu, benda 1 dan 2 memiliki nilai suseptibilitas sama, yaitu 0,0005 SI diinterpretasikan sebagai porpiri dan pyrrhotites, benda 3 dengan nilai suseptibilitas 0,0057 SI diinterpretasikan sebagai batuan porpiri, benda 7 dan 8 dengan nilai suseptibilitas masing-masing 0,0024 SI dan 0,0018 SI yang keduanya diinterpretasikan sebagai pirit. Terletak antara 90 meter - 350 meter dan merupakan batuan pembawa mineral emas.

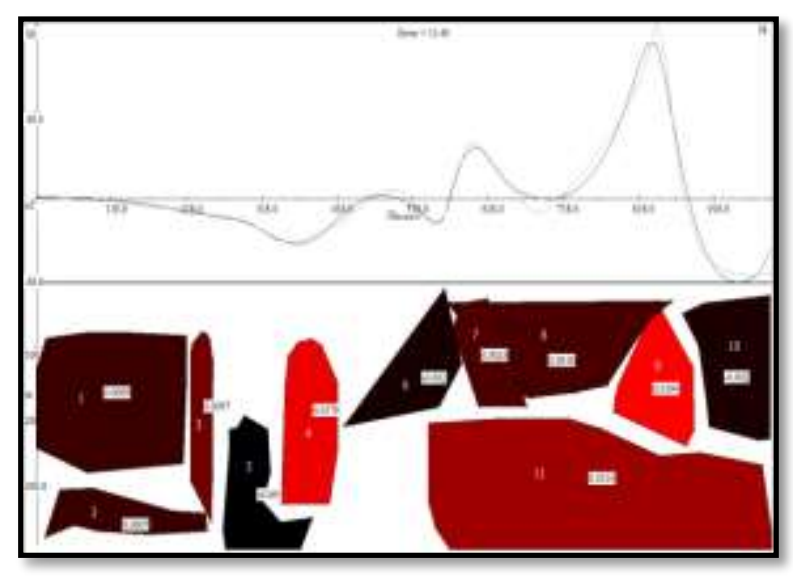

Gambar 10 Kurva dan bentuk benda anomali hasil pemodelan sayatan D-D'. (Error antara data pengukuran dan hasil pemodelan sebesar $11,40 \%)$.

Model sayatan E-E' pada Gambar 11 dengan arah baratlaut - tenggara, diperoleh 11 bentuk batuan yang memiliki nilai suseptibilitas yang berbeda-beda, dari ke-11 bentuk batuan tersebut terdapat 8 buah benda yang memiliki nilai kontras suseptibilitas yaitu, benda $4,5,6$, dan 7 dengan nilai suseptibilitas masing-masing benda 0,0036 SI, 0,0018 SI, 0,0038 SI, 0,0019 SI diinterpretasikan sebagai batuan yang sama, yaitu pirit, benda 8,9 dan 10 juga memiliki nilai suseptibilitas yang sama, yaitu 0,0001 SI dan ketiganya diinterpretasikan sebagai kalkopirit, dan benda 11 dengan nilai suseptibilitas 0,0008 
SI diinterpretasikan sebagai porpiri, Troilte dan pyrrhotites, dengan kedalama antara 50 meter - 350 meter dan merupakan batuan pembawa mineral emas.

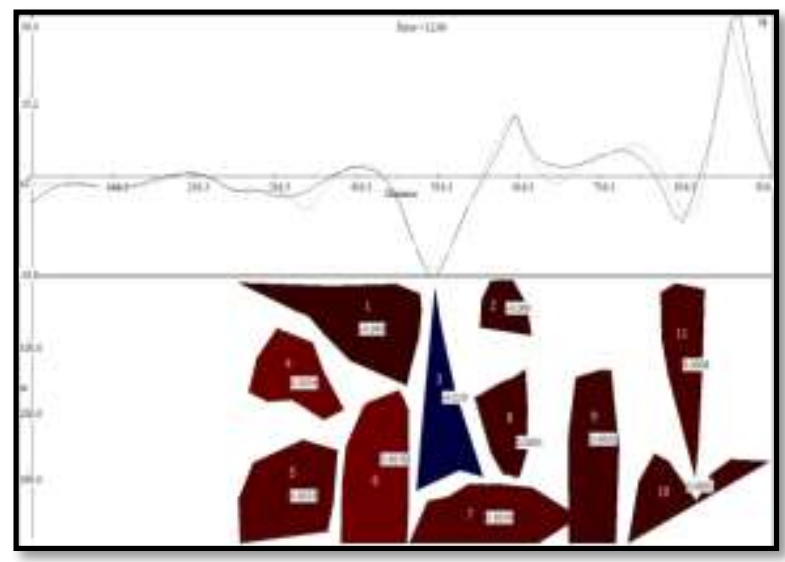

Gambar 11 Kurva dan bentuk benda anomali hasil pemodelan sayatan E-E'. (Error antara data pengukuran dan hasil pemodelan sebesar $12,66 \%)$.

Pada Tabel 2 tersebut juga terlihat adanya batuan mineral siderite dengan nilai suseptibilitas 0,0013 SI - 0,011 SI, yang mana diketahui bahwa batuan ini merupakan salah satu mineral magnetik yang terbentuk pada lingkungan sedimen, dan terdapat sebagai lapisan-lapisan yang sering berasosiasi dengan lapisan lempung, serpih, atau batubara. Dapat pula terbentuk melalui proses hidrotermal dan terdapat dalam urat-urat, atau terbentuk sebagai pegmatit. Sering berasosiasi dengan bijihbijih metal yang mengandung mineralmineral perak seperti pirit, kalkopirit, tetrahedrit, dan galena.

Berdasarkan Tabel 2 batuan yang diduga merupakan batuan pembawa mineral emas adalah pirit, kalkopirit, Troilite, pyrrhotites, siderite dan porpiri yang berasosiasi dengan batuan beku, iron sulfides dan mineral magnetik. Penyebaran batuan-batuan yang diduga merupakan batuan pembawa mineral emas ini menyebar pada sisi bagian Timur dan Selatan sampai bagian Utara pada lokasi penelitian dengan kedalaman yang berbeda-beda.

Struktur geologi dalam penelitian ini berupa sesar yang ada dalam wilayah penelitian. Bentukan struktur geologi (sesar) tersebut merupakan jalur transportasi mineral-mineral dalam lingkungan hidrotermal. Hal ini diperkuat dengan adanya adanya bentukan struktur sesar di wilayah daerah penelitian, tepatnya pada sisi bagian timur yang memanjang dari utara ke selatan dan pada sisi bagian barat pada lokasi penelitian yang diduga merupakan proses pengendapan oleh larutan hidrotermal melalui rekahan sebagai pengontrol jalur terjadinya proses mineralisasi di daerah tersebut.

Penelitian sebelumnya menghasilkan Wilayah Poboya dan sekitarnya, didominasi oleh batuan kuarsa sebagai pembawa mineral emas yang terdapat dalam urat kuarsa. Batuan kuarsa adalah jenis batuan utama yang membentuk struktur patahan, serta menjadi faktor penting terbentuknya emas. Lowell dan Guilbert dalam Pirajno (1992), batuan kuarsa ini selalu menghadirkan mineral-mineral ubahan 
seperti biotit, magnetit, kuarsa, karbonat (kalsit, siderite, rodokrosit), anhidrit, Illitserisit, Klorit, Epidot, kalkopirit, pirit, molibdenit, dan bornit yang tergolong dalam zona alterasi tipe potasik.

Batuan kuarsa yang diduga merupakan lapisan pembawa mineral emas ini dari hasil penampang lintasan 1 dan lintasan 2 memiliki arah bentangan utara ke selatan. Nnampak terlihat bahwa penyebaran batuan kuarsa ini menebal ke arah timur dan barat daya. Pada lintasan 3 yang arah bentangannya dari barat ke timur bahwa batuan kuarsa ini menebal pada arah selatan, selatan tenggara, utara dan timur laut. Kedalaman batuan kuarsa yang diduga merupakan lapisan pembawa emas ini memiliki kedalaman yang berbeda-beda pula pada setiap lintasan. Titik duga batuan kuarsa yang diduga sebagai lapisan pembawa mineral emas terletak pada kedalaman antara 2 meter - 16 meter dan kedalaman 34 meter - 60 meter bawah muka tanah (bmt).

Dalam hasil penelitian menggunakan metode magnetik ini, berdasarkan hasil interpretasi pemodelan 2D menggunakan software Mag2dc mengenai gambaran bawah permukaan, batuan kuarsa yang terdeteksi terdapat pada model sayatan A-A' pada benda 1 dan 2 dengan nilai suseptibilitas 0,0044 SI dan pada sayatan CC' yaitu pada benda 6 dengan nilai suseptibilitas 0,0044 SI dengan letak kedalaman 75 meter sampai 240 meter bawah muka tanah (bmt).

Berdasarkan pemaparan hasil interpretasi menunjukan bahwa hasil penelitian yang dilakukan dan sebelumnya sudah sesuai dengan keadaan geologi lokasi penelitian. Penyebaran batuan pembawa mineral emas ini memiliki kedalaman berbeda-beda pada setiap sayatan. Oleh karena itu diperlukan penelitian geofisika lebih detail sebagai pendekatan ilmiah yang lebih akurat untuk mengetahui penyebaranpenyebaran mineralisasi emas di lokasi penelitian.

Berdasarkan hasil penelitian tentang studi zona mineralisasi emas menggunakan metode magnetik di Lokasi Tambang Emas Poboya untuk mengetahui sebaran mineralisasi emas, disimpulkan bahwa zona mineralisasi emas yang berada dilokasi penelitian berasosiasi dengan mineral lain seperti Pirit $\left(\mathrm{FeS}_{2}\right)$ dengan nilai suseptibilitas 0,000035 SI - 0,005 SI, Kalkopirit $\left(\mathrm{CuFeS}_{2}\right)$ dengan nilai suseptibilitas 0,000023 SI - 0,0004 SI, Troilite dengan nilai suseptibilitas 0,00061 SI - 0,0017 SI, Pyrrhotites dengan nilai suseptibilitas 0,00046 SI - 1,4 SI, Porpiri dengan nilai suseptibilitas $0,00025 \mathrm{SI}-0,21$ SI, dan Siderite dengan nilai suseptibilitas 0,0013 SI - 0,011 SI, yang berasosiasi dengan batuan beku, iron sulfides dan 
mineral magnetik. Penyebaran batuanbatuan pembawa mineral emas ini terdapat pada sisi bagian timur dan selatan hingga pada bagian utara lokasi penelitian dengan kedalaman berkisar rata-rata antara \pm 70 meter sampai \pm 320 meter bawah muka tanah.

Perlu dilakukan penelitian geofisika lainnya lebih lanjut secara detail untuk mengetahui lebih jauh besar potensi penyebaran-penyebaran zona mineralisasi emas di lokasi tambang emas poboya secara keseluruhan, berdasarkan luas areal pertambangan tersebut. Salah satu yaitu melakukan pemetaan dengan menggunakan Aplikasi Pengindraan Jauh $(P J)$ dan Sistem Informasi Geografis $(S I G)$

\section{UCAPAN TERIMA KASIH}

Ucapan terima kasih, penulis sampaikan kepada Dr. Rustan Efendi, S.Si., MT dan Sandra, S.Si., MT selaku dosen pembimbing yang sudah banyak membantu penulis dalam menyelesaikan tugas akhir ini. Penulis juga ucapkan terima kasih kepada teman-teman dan semua pihak yang terlibat khususnya team pengambilan data.

\section{DAFTAR PUSTAKA}

Alpinus, 2010, Pemetaan Lapisan Pembawa Mineral Emas Di Kelurahan Poboya Kecamatan Palu Timur Propinsi Sulawesi Tengah, Skripsi Jurusan Fisika FMIPA, UNTAD, Palu.
ESDM, 2011, Data Potensi Sumber Daya Mineral Propinsi Sulawesi Tengah Sesuai dengan Peraturan Pemerintah Nomor 23 Tahun 2010, Dinas Energi dan Sumber Daya Mineral Propinsi Sulawesi Tengah, Palu.

Faeyumi, M., 2012, Sebaran Potensi Emas Epitermal Di Areal Eksploitasi PT Antam Unit Geomin, Tbk Kecamatan Nanggung Kabupaten Bogor, Skripsi Program Studi Geografi FMIPA, Universitas Indonesia.

Hunt, C. P., Moskowitz, B. M., Banerjee, 1995, Magnetik Properties of rock and minerals. In: Ahrens, Rock Physics and Phase Relations, A Handbook of physical Contants, American Geophysical Union.

Ismail, 2010, Metode Geomagnetik, Jurusan Fisika Fakultas Matematika Dan Ilmu Pengetahuan Alam Universitas Sebelas Maret, Surakarta.

Pirajno, 1992, Hydrotermal Mineral Deposit., Principles and Fundamental Concepts for The Exploration Geologist, Springer Verlag, Berlin, Heidenberg, New York, London, Paris.

Rosanti, D. F., 2012, Kolerasi antara Suseptibilitas Magnetik dengan Unsur Logam Berat Pada Sekuensi tanah di Pujon Malang., Skripsi Universitas Negeri Malang.

Silo, 2011, Media Aspirasi Rakyat (Jangan Ganggu Tahura Poboya), Yayasan Merah Putih (YMP), Palu, Sulteng.

Siahaan, B. U. B., 2009, Penentuan Struktur Pada Zona Hydrokarbon Daerah " $X$ " Menggunakan Metode Magnetik, Skripsi Program Geofisika Jurusan Fisika FMIPA, Universitas Indonesia.

Sukamto, R., Sumadirdja, H., Suptandar, T., Hardjoprawiro, R., dan Sudana, D., 1973, Peta Geologi Tinjau Lembar 
Agustus 2016

Palu, Sulawesi, skala 1:250.000,

Pusat Penelitian dan Pengembangan

Geologi, Bandung.

Telford W. M, Geldart L. P. dan Sheriff R.

E, Keys D. A., 1976, Applied

Geophysics, Second Edition,

Cambridge University Press, New York.

Ulinna'mah, L. I., 2011, Identifikasi Struktur Geologi Menggunakan Metode Magnetik Di Daerah Prospek Emas Desa Tutugan Kabupaten Banyumas, Skripsi Program Studi Fisika, Fakultas Sains dan Teknik Jurusan MIPA Universitas Jenderal Soedirman, Purwokerto. 